\title{
The Synergy between the SAAIR Conference Events and South African Higher Education Policy Initiatives during 1994-2015
}

Jan Botha

\section{Introduction}

The focus areas of Institutional Research (IR) practitioners in South Africa and an analysis of the synergy between these focus areas and the major higher education policy developments during the first two decades of the democratic dispensation in South Africa are the concerns of this chapter. To what extent did these policy developments determine the priorities of IR practitioners, or, to what extent did the results of the work of IR practitioners provide the evidence on which these policies were based? Or, is this a complex, dynamic relationship and that plays out in both directions at different times and in different contexts? Despite various voices arguing for multiple new roles for IR, for example, Swing (2009), and Calderon and Webber (2015), Saupe's (1981) and Dressel's (1981) classic definition that IR is conducted to support institutional management, and by implication, to provide evidence on which (policy) decisions can be based, remains a valid expression of what institutional leaders and policy makers expect from IR. On the other hand, the extent to which higher education policy makers actually base their decisions on the information provided by IR practitioners, is not easy to demonstrate definitively with empirical evidence. Therefore no assertions will be made in this chapter regarding any possible causal link between higher education policy developments and the work of IR practitioners, and consequently the softer term "synergy" was chosen to characterise the aim of the study.

Volkwein, Liu \& Woodell (2012) analysed the diversity and maturity of IR as a profession in the USA in terms of the size of IR offices and the range of tasks for which these offices are responsible. They illustrate that the nature of IR greatly depends on the environment in which a particular institution is embedded. In his study of the functions and priorities of institutional research offices across the world, Chirikov (2013:458) argues that IR is a contextual phenomenon which must be explored in particular settings. In Chapter 4 of this book the results of a similar study conducted among South African higher education institutions are reported. Moving beyond the diverse ways in which IR is organised and how it operates within higher education institutions, Kehm (2009:61-62) describes in broad strokes the differences in what she calls the "European model" of higher education research (including IR), with its focus on higher education policy at the macro-level (national and system-wide policies), and the "American model" with its practical focus at the meso-level of institutional improvement and the micro-level of academic practice. While the focus areas and priorities of IR practitioners in South Africa have been influenced by developments 
in other parts of the world (see Chapter 2), these priorities reflect in many ways the circumstances of this country during the first two decades of the democratic dispensation when higher education went through major changes.

The story of IR in South Africa will be explored in this chapter, on the basis of an analysis of the conference events of the Southern African Association for Institutional Research (SAAIR) from 1995 to 2015 and analysis of the demographics of the individuals who were responsible for these programme events. The term "conference events" is used in this chapter to refer to all different types of events listed on the conference programmes, including the keynote addresses, contributed papers, invited papers (other than keynote addresses), workshops, demonstrations, panel discussions and poster presentations. Thus far the SAAIR has not published the papers presented at the conferences, therefore, to avoid confusion with the official category of publication outputs recognised by the Department of Higher Education and Training (DHET 2015:17), the term "Conference Proceedings" is not used in this chapter.

SAAIR is an association of practitioners that was established in 1994 "to benefit, assist, and advance institutional research leading to improved understanding, planning and operation of institutions of higher education" in the Southern African region (SAAIR 1994, par 2.1). Rusaw (1995) and Merriam, Caffarella and Baumgartner (2012) illustrate how practitioner associations (tracing its origins to medieval guilds) acquired a modern form during the late $19^{\text {th }}$ century. Volunteer associations now typically include the following functions: to satisfy the need for social interaction of people doing the same work, to provide opportunities to share ideas and experiences (for example, through papers at conferences), to protect the interests of members working in the craft, to collectively develop solutions to common problems in the field of work, and to create opportunities for learning to develop the skills of members. In short, associations aim to "professionalise" the work in a specific area. Whether an association takes on a formal statutory status and is formally established as a professional association, or whether it chooses to operate on a more informal basis, the distinguishing characteristic of associations remains its focus on the interests of people engaged in the same field of work.

A wide range of volunteer associations exist in South African higher education. In addition to the learned associations of academic disciplines, there are also various associations of practitioners and professionals employed in the professional and support services in higher education institutions.

Table 1: Practitioner Associations in South African Higher Education

\begin{tabular}{|l|c|}
\multicolumn{1}{|c|}{ Name of association } & Abbreviation \\
\hline Association of South African University Directors of Information Technology & ASAUDIT \\
\hline Campus Protection Society South Africa & CAMPROSA \\
\hline Committee for Directors of Higher Education Libraries in South Africa & HEDSA \\
\hline Higher and Further Education Disability Services Association & HELTASA \\
\hline Higher Education Learning and Teaching Association of Southern Africa & IEASA \\
\hline International Education Association of South Africa & - \\
\hline Higher Education Legal Practitioners' Forum & \\
\hline
\end{tabular}




\begin{tabular}{|l|c|}
\hline South African Association of Campus Health Services & SAACHS \\
\hline South African Association of Senior Student Affairs Professionals & SAASSAP \\
\hline South African Facilities Management Association & SAFMA \\
\hline South African Higher Education Community Engagement Forum & SAHECEF \\
\hline South African Institute for Advancement & SAIA \\
\hline University Sport South Africa & USSA \\
\hline Southern African Association for Counselling and Development in Higher Education & SAACDHE \\
\hline Southern African Association for Institutional Research & SAAIR \\
\hline Southern African Research and Innovation Management Association & SARIMA \\
\hline
\end{tabular}

In most cases there are international associations with whom these South African entities are associated. The impact of these associations on higher education in South Africa, and an understanding of their contributions to the well-being and development of higher education, is an under-researched area of study. This chapter on the SAAIR wants to address this gap with reference to one of these associations.

Among the shared characteristics of these associations (also referred to as institutes, forums, societies or even committees) are that they are set up by volunteers in a particular area of work and not through a statute of government, and that they are not-for-profit organisations. Associations value their independence to set their own agenda. The activities of these associations therefore provide an interesting window on the focus areas and priorities in the different areas of work in higher education. The papers presented the conferences of volunteer associations are perhaps the most visible evidence of what practitioners choose to do when they have the opportunity to set their own agenda independent of the instructions of their line managers.

Following the establishment of the Association of Institutional Research (AIR) in the USA in 1960, similar volunteer professional associations in this area of work in higher education have been established in almost all regions of the world, including Southern Africa, with the establishment of SAAIR in 1994 (Reichard 2012:11, Chirikov 2013:459). Notably, this was the same year in which South Africa became a constitutional democracy, a development that has led to far-reaching changes in the country as a whole, including the higher education system. The IR agendas of the IR offices in universities often reflect national higher education trends and policies (Chirikov 2013:459), and this has also been the case in South Africa. In this chapter, I undertake an analysis of the conference events of the SAAIR Annual Conferences from 1994 to 2015 to illustrate the synergy between the priorities of IR practitioners - when they participate on a voluntary basis in the activities of the SAAIR and the major policy-development periods in South African Higher Education since 1994. The documents that served as the sources for the data are the official programmes of the Annual Conferences of the SAAIR. Until 2010 the SAAIR did not have an administrative office responsible for the maintenance of an archive of the documents of the Association, so the conference programmes of some of the conferences during the first decade of SAAIR's existence had to be collected from the personal records of members who attended those 
conferences. It was possible, however, to get hold of a full set of conference programmes covering the years 1994-2015. This type of documents is what Bryman (2008:522) calls "official documents from private sources", such as company documents. He lists this type of documents as one of a heterogenous group of sources that is often used by organizational ethnographers as part of their investigations.

In the first part of this chapter I report the results of an analysis of the demographic and institutional profile of the individuals who presented the papers or were responsible for the workshops or demonstrations and other SAAIR conference events during 1994-2015. I then analyse higher education policy developments during this same period in South Africa. Four distinct sub-periods are distinguished. Following that, I map the SAAIR conference events onto these four periods and illustrate and explain the synergy between the policy priorities of the four periods and the conference events.

\section{Demographic and institutional profile of the participants responsible for SAAIR conference events, 1994-2015}

I extracted data from the conference programmes of the annual SAAIR conferences to compile a demographic profile of the conference presenters (gender, race and institutional affiliation). Although presenters are not required to indicate their gender and race when they present a paper or other type of event, I was able to obtain this information through enquiries to former and present members of the executive committee SAAIR.

A total of 560 conference events were presented in the period 1994-2015 by a total of 485 individuals. A number of individuals were responsible for more than one of the events, including 24 IR practitioners who were each responsible for more than five conference events during the period of analysis.

The conference events consist of ten different types of contributions.

Table 2: Types and distribution of SAAIR conference events

\begin{tabular}{|l|r|r|}
\multicolumn{1}{c|}{ Type of conference proceeding } & Number & Percentage \\
\hline Contributed paper & 447 & 80 \\
\hline Keynote Address & 32 & 6 \\
\hline Invited paper & 21 & 4 \\
\hline Demonstration & 18 & 3 \\
\hline Open forum & 13 & 2 \\
\hline Workshop & 10 & 2 \\
\hline Pre-conference workshop & 6 & 1 \\
\hline Panel discussion & 5 & 1 \\
\hline Poster presentation & 4 & 1 \\
\hline Table-top session & 4 & 1 \\
\hline TOTAL & $\mathbf{5 6 0}$ & $\mathbf{1 0 0}$ \\
\hline
\end{tabular}


During the period of analysis, 29 individuals presented keynote addresses at SAAIR annual conferences, including four vice-chancellors of South African universities, 14 eminent international scholars, and various high-ranking officials in government departments or other higher education statutory bodies in South Africa, Botswana and Mauritius. The conference themes are formulated and decided by the Executive Committee. Keynote speakers are invited to speak on a topic directly related to the conference theme of that particular year. Other contributors to the SAAIR events are not required to relate their presentation directly to the conference theme, as long as their contribution falls within the ambit of the goals of the SAAIR. The themes of the conference events that are analysed in the next section (including the keynote papers) reflect therefore, collectively, the focus areas of the SAAIR members and the Executive Committee.

With the exception of the keynote papers and invited papers, which were presented by highly reputable individuals carefully selected by the SAAIR Executive Committee, all the types of events were submitted in response to the call for papers issued annually by the Executive Committee, and only submissions that passed a double-blind peer-review process were accepted for presentation. For the purposes of the analysis presented in this chapter, all the different types of conference events have been treated as a collective consisting of a total of 560 discrete events listed on the conference programmes.

By far the majority of the presenters (76\%) were white, followed by approximately onefifth who were African, with Indian and Colored presenters constituting small minorities of $4 \%$ and $2 \%$ each, respectively. Participation of African, Coloured and Indian members has increased from 20\% (1994-2000) to 29\% (2009-2015). The gender breakdown of the presenters is as follows: male $61 \%$ and female $39 \%$. In terms of the SAAIR's membership model, individuals who present papers or are responsible for any of the other types of conference events become members of the Association for that calendar year. Therefore, this analysis of the profile of the contributors to the conference events also represents the profile of a portion of the members of the Association. This demographic profile highlights the need for the SAAIR to build on the success of its staff development opportunities (for details, see Chapter 2) and enhance its efforts to become more representative in terms of race and gender so that the transformation goals for the higher education sector as a whole will also reflect in the profile of contributors to conference events and profile of the membership of SAAIR.

In terms of type of institution, and as Table 2 below illustrates, individuals employed by South African public higher education institutions (universities, comprehensive universities, and universities of technology) represent by far the majority of the presenters, with only a small number of presenters affiliated to other types of institutions in South Africa and to institutions outside South Africa. Only 4,5\% of the conference events were presented by individuals from African countries outside South Africa. When the Higher Education Research and Advocacy Network in Africa (HERANA) initiated their project on the comparison of the institutional performance of so-called flagship universities in eight different African countries, it transpired that the higher education institutions in many of the SAAIR countries (excluding South Africa) found it difficult to provide the required institutional information because they have not yet established dedicated IR offices (HERANA 2012). Due to the increase in reporting responsibilities in all countries (see Chapter 10) it can be expected that the number of IR 
practitioners in the Southern African countries outside South Africa will increase, and with that the level of their participation in the activities of the SAAIR will also increase.

Table 3: Types of institutions where presenters were located

\begin{tabular}{|l|r|r|}
\hline \multicolumn{2}{|l|}{ Location and type of institution } & \multicolumn{1}{|c|}{ Percentage } \\
\hline Universities in South Africa & 67,4 & \\
\hline South African Public University (Traditional universities and Comprehensive Institutions) & 17,5 & \\
\hline South African Public University of Technology & 1,5 & \\
\hline South African Private Higher Education Institution & 1,4 & \\
\hline Universities in Africa outside South Africa & 1,3 & \\
\hline Public University in Botswana & 0,4 & \\
\hline Private Higher Education Institution in Botswana & 0,2 & \\
\hline Polytech in Namibia & 0,2 & \\
\hline A university in Tanzania & 0,1 & \\
\hline Private Higher Education Institutions in Namibia & 0,1 & \\
\hline Public University in Mozambique & 0,1 & \\
\hline Public University in Swaziland & & \\
\hline Public University in Mauritius & & $\mathbf{3 , 2}$ \\
\hline Universities outside Africa & 2,6 & \\
\hline Non-university Institutions in South Africa & 1,9 & \\
\hline Government Departments & 0,8 & \\
\hline Commercial Companies & 0,6 & \\
\hline Non-governmental organisations & & $\mathbf{0 , 7}$ \\
\hline Statutory Agency & & $\mathbf{1 0 0}$ \\
\hline Non-university institutions in Africa outside South Africa & & \\
\hline
\end{tabular}

In the next section of this chapter, where the results of an analysis of the synergy between the topics of the conference events and South African higher education policy initiatives are presented, the conference events presented by participants outside South Africa were not taken into account.

Given that the University of South Africa (UNISA), an open and distance-learning institution with almost 350000 students, has by far the biggest IR office of all the universities in South Africa, it is not a surprise that the largest number of the SAAIR conference events came from this institution. The three institutional types into which public institutions are classified in South Africa are all represented in the top 20 institutions contributing to the SAAIR conference events (see Table 4 below), including nine of the eleven (traditional) universities, five of the six comprehensive institutions, and five of the eight universities of technology. The three new institutions established during 2014 and 2015 have not yet participated in activities of the SAAIR. The University of Botswana is the only institution in a country outside South Africa in the list of top 20. 
Table 4: The twenty institutions responsible for the highest number of the SAAIR conference events

\begin{tabular}{|l|c|c|}
\hline Institution & Type* & Total \\
\hline University of South Africa & Compr & 161 \\
\hline Stellenbosch University & Univ & 68 \\
\hline University of Johannesburg & Compr & 56 \\
\hline Tshwane University of Technology & UoT & 50 \\
\hline University of the Free State & Univ & 42 \\
\hline University of KwaZulu-Natal & Univ & 37 \\
\hline University of Cape Town & Univ & 33 \\
\hline University of Pretoria & Univ & 28 \\
\hline Nelson Mandela Metropolitan University & Compr & 24 \\
\hline Walter Sisulu University & Compr & 21 \\
\hline Cape Peninsula University of Technology & UoT & 21 \\
\hline North West University & Univ & 20 \\
\hline University of the Witwatersrand & Univ & 16 \\
\hline Vaal University of Technology & UoT & 15 \\
\hline University of the Western Cape & Univ & 14 \\
\hline Mangosuthu University of Technology & UoT & 13 \\
\hline Central University of Technology & UoT & 13 \\
\hline University of Fort Hare & Univ & 12 \\
\hline University of Botswana & - & 12 \\
\hline University of Zululand & Compr & 7 \\
\hline
\end{tabular}

* Comprehensive Institutions (Compr), traditional universities (Univ) and universities of technology (UoT).

\section{Four periods in higher education policy development in South Africa}

One of the first initiatives of Nelson Mandela when he became president of South Africa in 1994 was to appoint the National Commission on Higher Education (NCHE). The brief of the NCHE was to conduct a thorough investigation of the state of higher education in South Africa, and to make proposals to the country's first democratic government for the transformation of the entire higher education system, to ensure better alignment with and responsiveness to the needs of the country (NCHE 1996). The work of the NCHE initiated a far-reaching and unprecedented process of policy development that guided government initiatives and institutional activities over the next 20 years that have determined the context for the work of IR practitioners.

Combining the periodisations of South African Higher Education policy developments proposed by Muller, Maassen \& Cloete (2006), Badat (2009) and Lange (2012), Lange \& Luescher-Mamashela (2016:112) propose the following three periods, with brief description of the defining characteristics of each in terms of policy development at system and institutional levels. 
Table 5: Periodisation of governance, leadership and management

\begin{tabular}{|l|l|l|}
\multicolumn{1}{|c|}{ Periodisation } & \multicolumn{1}{c|}{ System-Ievel characterisation } & \multicolumn{1}{c|}{ Institution-level characterisation } \\
\hline 1994-2000 & $\begin{array}{l}\text { Political consensus, implementation vacuum } \\
\text { and the setting up of government }\end{array}$ & $\begin{array}{l}\text { Democratisation and the unfolding of } \\
\text { institutional governance }\end{array}$ \\
\hline 2001-2009 & $\begin{array}{l}\text { Policy contestation, state steering and the rise } \\
\text { of the 'evaluative state' }\end{array}$ & $\begin{array}{l}\text { Assimilating steering mechanisms: Merger } \\
\text { governance, the rise of managerialism and } \\
\text { post-managerialism }\end{array}$ \\
\hline 2009-2014 & $\begin{array}{l}\text { State managerialism and the question of } \\
\text { democratic accountability }\end{array}$ & $\begin{array}{l}\text { Managing identity and institutional crises: } \\
\text { Towards knowledge-based management }\end{array}$ \\
\hline
\end{tabular}

(Source: Lange \& Luescher-Mamashela (2016:112)

For the purposes of the analysis in this chapter I use broadly the same periods, but split the 2001-2009 period into two discrete periods, i.e. 2001-2005 and 2006-2008. This is based on the impact on the work of IR practitioners of policies that were introduced during these two periods (and partly because these two periods largely overlap with the terms of office of two different cabinet ministers responsible for higher education). The four periods used in this analysis are:

Period A 1994-2000: the laying out of common principles and values for higher education (with an emphasis on access, equity, redress) and the democratisation of the higher education system epitomised by the implementation of the notion of cooperative governance.

Period B 2001-2005: from the launch of the National Plan for Higher Education (NPHE) in 2001 to the end of the institutional mergers around 2005, a period overlapping largely with the period when Professor Kader Asmal was in office as Minister of Education (as this ministry was known from 1994-2009 when it was responsible for basic education and higher education).

Period C 2006-2008: the introduction of a new funding framework and a new mode of enrolment planning, overlapping largely with the period when Ms Naledi Pandor served as Minister of Education.

Period D 2009-2015: the subdivision of the Department of Education into two departments (Basic Education and Training; and Higher Education and Training). During this period various changes in the Higher Education Act were made in terms of which Government control over higher education leading was expanded, inter alia, through the introduction of extended reporting requirements (see Chapter 9), and the publication of a new White Paper setting out policy goals for the post-secondary school system as a whole (Department of Higher Education and Training 2014).

\section{Classification and mapping of the SAAIR Conference events}

In an analysis of the frequency of specific topics and concepts in the titles of the SAAIR Conference events (Botha 2015:123) over the period 1994-2015, I have developed a framework consisting of eight categories to classify the topic of the conference events into broad themes: 
1) IR in support of institutional planning, the provision and management of information, and the monitoring of implementation (see Chapters 6-7 and 9-10 of this book).

2) Quality assurance and evaluation (see Chapter 8).

3) Teaching and learning and curriculum development (see Chapters 11-13).

4) Knowledge production (research) (see Chapter 15).

5) Community engagement (see Chapter 16).

6) Postgraduate studies (see Chapter 14).

7) International benchmarking of IR and learning from best practice elsewhere.

8) The instruments and practices of IR.

When these themes and categories are mapped onto the four periods in national policy development discussed above, it yields the following distribution of the themes across the different periods.

\section{Changes in the level of interest in each theme across the four periods.}

Theme 1: IR in support of institutional planning, the provision and management of information, and IR conducted as part of monitoring the implementation of institutional initiatives and actions. At 58\% in Period A, it represents the highest individual incidence of any theme in any of the four periods. Period A (1994-2000) covers the early period of IR in South Africa; IR practitioners worked only or mainly on this core IR function. During period A Higher Education was revised and re-planned to match the needs of a society in social, political and economic transition. The drop in period B in the prevalence of this theme, to $34 \%$, is surprising, as this was the transformation/merger period (2001-2005). However, the large number of papers emanating from a joint venture in 2002 of the SAAIR with South African Association for Research and Development in Higher Education (SAARDHE), which was focused on teaching and learning, tipped the scale away from the planning, information and monitoring focus towards teaching and learning. The rise to $47 \%$ for theme 1 in period $\mathrm{C}$ can be ascribed to the emergence of the detailed enrolment planning required by the then Department of Education from 2006. By period D the SAAIR conference events focusing on planning, information and monitoring dropped to $24 \%$, the lowest level of all four periods. By period D (2009-2015), the higher education system had stabilized in terms of radical institutional re-organisation, and the focus shifted to efficiency, tighter government control and the broader post-secondary system.

Theme 2: The theme of Quality Assurance (QA) was present in the SAAIR conference events across all four periods at more or less same the level of $10 \%$. The Council on Higher Education (with its permanent Higher Education Quality Committee (HEQC) had not yet been established in period A. However, during Period A, the Certification Council for Technikon Education (SERTEC) (established in 1988) and of the Quality Promotion Unit (QPU) of the South African Universities Vice-Chancellors Association (SAUVCA) (established in 1996 and dissolved in 1999) were responsible, at national level, for QA in higher education (CHE 2000). The QPU conducted the first institutional reviews in South Africa. The activities of the QPU probably resulted in a sizable presence of QA conference events in this period. Papers on quality assurance were presented at the very first conference of the SAAIR in 1994. Conference events focusing on QA reached its highest level (15\%) in period C, which 


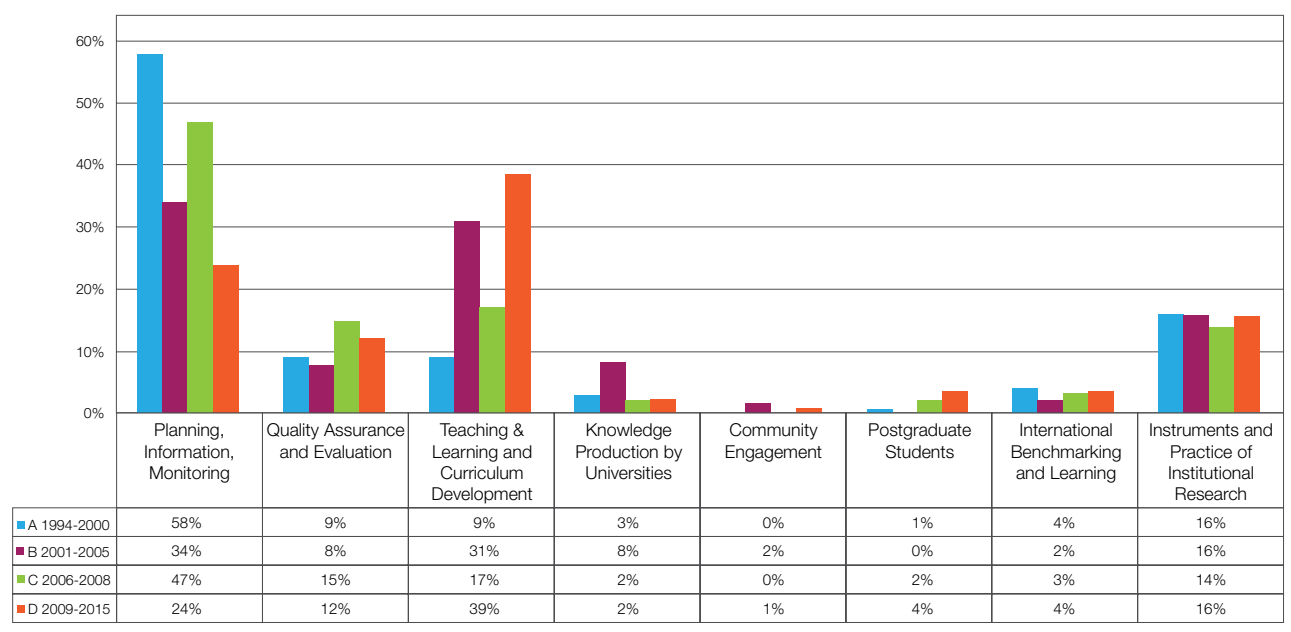

Figure 1: Classification and mapping of SAAIR conference events

was when the first institutional audits took place under the auspices of the HEQC and when the HEQC's new programme accreditation system became fully operational. By period D, events with QA as theme tapered down slightly above the levels at which it evidenced during periods $A$ and $B$. This may be indicating that the system has matured and settled, and the emphasis on the institutional quality assurance management systems and the practices and instruments of QA has shifted to teaching and learning interventions aimed at quality enhancement.

Theme 3: Papers by SAAIR members on topics related to teaching and learning and curriculum development started at a fairly low basis of $9 \%$ during period A. Given the intense policy-making and planning activities during period $\mathrm{A}$, it is not surprising that teaching and learning and curriculum development did not feature more prominently. The increase to $31 \%$ in conference events related to teaching and learning and curriculum development during period B is most likely due to the joint Annual Conference of the SAAIR and the South African Association for Research and Development in Higher Education (SAARDHE) in 2002. A significant portion of the work of SAARDHE focused on research on teaching and learning. During period $C$ the conference events focusing on teaching and learning and curriculum development dropped to $17 \%$. The rise to $39 \%$ of the focus on teaching and learning and curriculum development during period D (surpassing the $28 \%$ focus on planning, information and monitoring in the same period) is significant given that Period D was characterised by a widespread awareness of the efficiency and throughput challenges in the higher education system, clearly identified through the HEQC's first round of institutional audits from 2004-2012. The Council on Higher Education's comprehensive study on undergraduate curriculum reform (Council on Higher Education 2013) and the Quality Enhancement Project (QEP) (Council on Higher Education, 2014) shifted the emphasis back to teaching and learning and curriculum development and this is also reflected in the sizable $39 \%$ of conference events focusing on this theme. 
Theme 4: The research function of universities (or, as it is referred to in this chapter, knowledge production by universities) is data-rich. The fact that this theme only registers a prevalence of $2-3 \%$ in the conference events of SAAIR during periods A, C and D is surprising. It seems that SAAIR members leave this crucial area of IR to their colleagues in the research administration and development offices (see Chapter 15 of this book).

Theme 5: Only five of the SAAIR conference events across all four periods, focused specifically on community engagement. This is surprising given the major emphasis in national policy on community engagement during the first 20 years of democracy. For example, in September 2006 the CHE organized a major international conference on community engagement (CHE 2007), and during the last decade most institutions have expanded and enhanced their community engagement activities and established dedicated organisational structures to coordinate these. Another indication of this enhanced interest in community engagement was the establishment of the South African Higher Education Community Engagement Forum (SAHECEF) in 2008 by a number of leading community engagement managers in different institutions. Nevertheless, of the three core academic activities, community engagement seems to retain a lower priority among South African IR practitioners. See, however, Chapter 16 for interesting new initiatives and perspectives.

Theme 6: From the analysis it is clear that most of the SAAIR conference events across all four periods focused on institutional issues (theme 1) and undergraduate teaching (theme 3 ), with much less attention to postgraduate studies. However, there was a slight increase in conference events focusing on postgraduate studies (from $1-2 \%$ during periods $\mathrm{A}, \mathrm{B}$ and $\mathrm{C}$ to $4 \%$ in period D), with a specific interest in doctoral education (see Chapter 14). As with the case of studies focusing on the research function of universities, the members of SAAIR seem to leave this area of institutional research to their colleagues in research development offices and in post graduate support offices. Analytical work focused on postgraduate studies and students is a critical gap in the work of SAAIR members.

Theme 7: IR is cross-institutional, cross-regional and cross-national because environmental scanning is considered to be one of the core responsibilities of IR practitioners (see Chapter 1). This interest is present across all four policy periods albeit, surprisingly, a fairly small proportion ( $2 \%$ to $4 \%$ ) of the SAAIR conference events have been dedicated to international learning and benchmarking of IR practice.

Theme 8: As could be expected from an association of practitioners, a constant level of interest of between $14 \%$ to $16 \%$ was maintained across all four periods in the practice of IR and in the tools/instruments used by IR practitioners. This interest remained at the same level, irrespective of the different emphases and priorities across the four different policy periods. 


\section{Conclusion}

The analysis of the SAAIR's conference events reported in this chapter provided evidence of a synergy between national policy developments and the interests and activities of institutional research professionals in South African Higher Education institutions.

One of the most significant findings of the analysis of the SAAIR conference events was the decrease, from Periods A to D, in the number of conference events focused on planning, information and monitoring (we may say, the traditional IR functions), and the concomitant increase in the number of conference events in teaching \& learning and curriculum development. Whereas conference events in the traditional IR fields of planning, information management and monitoring started at $58 \%$ in period $A$, events with these themes dropped to $24 \%$ in Period D. On the other hand, conference events focused on teaching and learning and curriculum development increased from a relatively low representation of $9 \%$ in period A to a notable $39 \%$ in period D. This finding points to a synergy between the work of IR practitioners and the national policy priorities in higher education on the enhancement of (undergraduate) teaching and learning and the improvement of student success.

In this chapter this relationship is intentionally referred to as a "synergy" because further research is required to substantiate any claims of causality, namely whether the work of IR professionals caused or informed certain policy decisions, or vice-versa, or to what extent the national policy developments caused (as a reaction/response) the particular themes on which IR practitioners have worked during the period of analysis. Since a number of the IR professionals active in the SAAIR work in various capacities (on task teams, or as consultants, or on short term contracts) at national level for different government departments and agencies, there is reason to believe that their work may have provided the evidence for certain policy decisions. However, to trace whether or not that work was also presented at SAAIR annual conferences will require further research which is beyond the scope of this paper.

Although there are links between the work of IR practitioners within the context of the SAAIR and national bodies such as the Council on Higher Education or government departments, SAAIR carefully maintains a healthy distance from any formal operational involvement in government departments and agencies. This is an expression of a general characteristic of volunteer associations, as I have argued at the beginning of this chapter. As an association, SAAIR has never been contracted by Government for specific projects, neither has it tendered to undertake any government projects.

At an institutional level, however, the situation is probably different. Since IR practitioners are employed by their institutions, and their work is largely determined by the instructions of their line managers, it is to be expected that the thematic content of their work is caused, or at least prompted, by institutional needs. However, also in this respect, there is some distance between the SAAIR conference events and specific institutional activities. IR practitioners value the freedom offered by their own professional association to go beyond the work and interests of their employers. The SAAIR provides an opportunity for creativity, experimentation and feed-back from peers. 


\section{References}

Botha, J. 2015. Institutional research in South Africa in the service of strategic and academic decision support, in K. Webber \& A. Calderon (eds.). Institutional Research and Planning in Higher Education: Global Context and Themes. New York: Routledge. 115-127.

Badat, S. 2009. Theorising institutional change: Post-1994 South African higher education. Studies in Higher Education, 34(4):455-467. http://dx.doi. org/10.1080/03075070902772026

Bryman, A. 2008. Social research methods. (Third edition). Oxford University Press.

Calderon, A.J. \& Webber, K.L. 2015. Institutional research, planning and decision support in Higher Education today, in A. J. Calderon \& K. L. Webber (eds.). Institutional Research and Planning in Higher Education: Global Contexts and Themes. Routledge. 4-15.

Chirikov, I. 2013. Research universities as knowledge networks: the role of institutional research. Studies in Higher Education, 38(3):456-469. http://dx.doi. org/10.1080/03075079.2013.773778

Cloete, N. \& Maasen, P. 2015. Roles of universities and the African context, in N. Cloete, P. Maassen \& T. Baily (eds.). Knowledge production and contradictory functions in African Higher Education. Cape Town. 1-31.

Council on Higher Education (CHE) 2000. An Evaluation of SERTEC and the Quality Promotion Unit. Pretoria: Council on Higher Education.

Council on Higher Education (CHE). 2007. Community engagement in higher education. Proceedings of the conference hosted by the Higher Education Quality Committee and the Community - Higher Education Service Partnerships Initiative of JET Education Services. Pretoria: Council on Higher Education.

Council on Higher Education (CHE). 2013. A proposal for undergraduate curriculum reform in South Africa: The case for a flexible curriculum structure. Pretoria: Council on Higher Education.
Council on Higher Education (CHE). 2014. Framework for institutional quality enhancement during the second period of quality assurance (QEP). Pretoria: Council on Higher Education.

Department of Higher Education and Training (DHET). 2014. Policy Framework on Differentiation in the South African Post-school System. . Available: http://www.dhet.gov.za/ Gazette/Policy\%20Framework\%20 on $\% 20$ Differentiation $\% 20$ in $\% 20$ the $\% 20$ South\%20African $\% 20$ Post $\% 20$ School\%20System.pdf. [2016, June 21]

Department of Higher Education and Training (DHET). 2015. Research outputs policy, 2015. Government Gazette No 38552, 11 March 2015.

Dressel, P. L. 1981. The shaping of institutional research and planning. Research in Higher Education 14(3): 229-258. http://dx.doi.org/10.1007/ BF00983391

Higher Education Research and Advocacy Network (HERANA). 2012. Research on higher education and development in Africa. Available: http://chet.org.za/ programmes/herana/ [2016, June 21].

Lange, L., Mauricio Saavedra, F., \& Romano, J. 2013. Institutional research in the emerging countries of Southern Africa, Latin America, and the Middle East and and North Africa: Global Frameworks and Local Practices. New Directions for Institutional Research, 157:23-38. http://dx.doi.org/10.1002/ ir.20037

Lange, L. 2012. The public purposes of the university: A historical review 1995-2010. In B. Leibowitz (ed.). Higher Education and the Public Good. Views from the South. Stellenbosch: SUN MeDIA.

Lange, L. \& Luescher-Mamashela, T. 2016. Governance. InSouth African Higher Education Reviewed. Two decades of democracy. Pretoria: Council on Higher Education. 105-142.

Merriam, S.B., Caffarella, R.S. \& Baumgartner, L.M. 2012. Learning in Adulthood: A Comprehensive Guide, John Wiley \& Sons. 
National Commission on Higher Education (NCHE). 1996. Report of the National Commission on Higher Education.

A framework for transformation. Pretoria: Government Printer.

National Planning Commission (NPC). 2012. National Development Plan 2013. Our future - make it work. Pretoria: Government Printer.

Reichard, D.J. 2012. The History of Institutional Research. In R. D. Howard, G. W. McLaughlin \& William E. Knight (eds.). The Handbook of Institutional Research. San Francisco. 3-22.

Rusaw, A.C. 1995. Learning by association: Professional associations as learning agents. Human Resource Development Quarterly, 6(2):215-226. http://dx.doi. org/10.1002/hrdq.3920060209

Saupe, J.L. 1981. The functions of institutional research. Association for Institutional Research (AIR): Tallahassee.
Southern African Association for Institutional Research, 1994. Constitution of the Southern African Association for Institutional Research (SAAIR) (as amended in 2010). Available: http:// www.saair-web.co.za/wp-content/ uploads/2016/01/SAAIR-amendedconstitution-Final-19-Aug-2010.pdf [2016, June 21].

Swing, R. L. 2009. Institutional researchers as change agents. New Directions for Institutional Research 143:5-16. http:// dx.doi.org/10.1002/ir.301

Volkwein, J.F., Liu, Y. \& Woodell, J, 2012. The structure and functions of institutional research offices, in R. D. Howard, G. W. McLaughlin, \& William E. Knight (eds.). The Handbook of Institutional Research. San Francisco: Jossey-Bass. 22-39.

Webber, K.L. \& Calderon, A.J. (eds.). 2015. Institutional Research and Planning in Higher Education: Global Contexts and Themes. New York: Routledge. 